\title{
Household Income and Expenditure Relationships: A Simultaneous Equation Approach
}

\author{
Nik Hashim Nik Mustapha, Noorhaslinda Kulub Abd. Rashid, Aslina Nasir \\ University of Malaysia Terengganu (UMT), Kuala Terengganu, Malaysia
}

\begin{abstract}
Income and expenditure are highlighted in this study as they currently affect the quality of life of the Malaysian society. In the Ninth Malaysia Plan (2006-2010) poverty eradication was emphasized as one of the socio-economic targets to uplift those poor households from the fast moving modern sectors of the economy. The primary objective of this paper is therefore to identify income and expenditure relationships among the households of the east coast of Peninsular Malaysia during the current economic downturn. Attempts to analyze household consumption as a share of total income and to identify factors contributing to household income and expenditure have become a topic of interest in literature. A substantial portion of household income devoted to productive loans characterizes the majority of Malaysians as the economy progresses to a more advance stage. A significant and strong relationship between income and types of household expenditure is explored from the socio-economic perspectives. Using primary data a system of simultaneous equations, namely the two stage least squares (2SLS) was applied. This paper identifies crucial variables associated with the income and expenditure. Some of these variables showing high correlation with the total expenditure are the housing loan, automobile loan and educational expenditure.
\end{abstract}

Keywords: expenditure, income, simultaneous two-stage equation method

\section{Introduction}

The slogan "spend wisely" is often promoted and advertised at the shopping centers as well as in the media. The slogan addresses the importance of economic and systematic spending in the current financial situation. Furthermore, the consumer consumption index (CCI) had shown a dramatic increment in the demand for goods and services compared to the pass years of economic crisis since 1997. The above scenario resulted from the spending behavior of Malaysians which eventually has a significant impact on the economic condition of the Malaysian as a whole.

One of the factors influencing the above phenomenon is the income level among the society which is the main factor that determines the individual consumption spending. However, income is not the only factor governing spending, other factors such as loan and saving contributed to the spending behavior. Spending behavior is driven

\footnotetext{
Nik Hashim Nik Mustapha, professor and deputy director, Centre for Socio-economic Development (CSD), University of Malaysia Terengganu (UMT).

Noorhaslinda Kulub Abd. Rashid, Lecturer, Faculty of Management and Economics, University of Malaysia Terengganu (UMT).

Aslina Nasir, research assistant, Faculty of Management and Economics, University of Malaysia Terengganu (UMT).
} 
by the needs to fulfill basic necessities of the individual household and the family. Furthermore, instability in economic situations and price changes that are taking place had undoubtedly influenced the disposable income of the society. Malaysians had just experienced increases in price of food and petroleum therefore, it is important to understand how far they spend their money wisely in a situation of global economic changes.

Zurawicki and Braidot (2004) reported that household tends to make an adjustment to their income and expenditures to fulfill their needs during the economic crisis or recession such as stagflation and the inflation. Stephen (2001) also disclosed the same findings indicating that changes in consumption and expenditure patterns occur due to changes in income level among the households.

\section{Issues in Household Expenditure}

The economic recessions and price fluctuations normally cause changes in socio-economic and social dimension which are related to the society's welfare. Changes in social dimension had exacerbated social crisis in the economic community system (Walton \& Manuelyan, 1998). This statement was supported by Atsushi Maki (2006), who reported that saving pattern during crisis had changed immediately in accordance with the individual household budget and thus influenced the current asset pricing whereby the debtor had to bear with the new situation.

The variation in expenditure and spending among households will eventually affect differences in lifestyle. Economic impact of this different lifestyle will exacerbate and widen the income disparity between rich and poor households. Household expenditure and income disparity can lead to significant differences in rural and urban location in terms of their expenses on basic needs. The urban household tends to increase their consumption based on the level and increment of their income in order to improve their lifestyle (Farkhanda \& Eatzaz, 2007). While, Beine, Bismans, Docquier and Laurent (2001), disclosed their findings whereby the households in United States prefer to spend their money in shopping centers rather than choose their leisure time for normal activities.

The east coast of Peninsular Malaysia, represented by Pahang, Terengganu and Kelantan was selected as the study area for the current investigation. A random sample of households for each state was selected for the analysis. The study is intended to investigate changes in household's consumption and spending priorities interchangeably with income during the economic crisis. More specifically, the objective of this study is to analyze households' income and expenditure patterns among the east coast population and to identify major components of households' expenditure as the percentage of total income for food, education, health and others using two stage econometric model.

\section{Literature Review}

In view of economic crisis, this study is deemed important for identifying the household's expenditure patterns in Malaysia. Ability to understand the household spending patterns particularly among the poor would be useful to manage their expenditure as preparation for any change in the economic uncertainties that are expected in the future. In addition, this study is focusing on efforts to overcome poverty either in urban or rural area.

Othman (1996) classified the efforts to poverty eradication into three categories, namely, sector approach, oriented group approach and individual approach. Typically, the sector approach is most studied in developing countries based on two reasons: First, the redistribution of income from taxpayers through direct public funds to 
the poor, and second how the poor benefited from the top-down to the targeted groups to the bottom (trickle-down effects). By this approach, the outside sectors will benefit more from the provision of utilities while the targeted group will receive benefit directly from government assistance programs. The oriented group approach classifies household into categories of poor people based on their socio-economic profiles such as income, family size, occupation and so forth. This approach is suitable and able to solve directly the incidence of poverty for those classified as poor according the specific definition provided. The individual approach identifies each unit of household in each location in terms of income, education and employment. Benefits from this approach are usually used by the Social Welfare Department.

Several literatures on consumption expenditure are cited here in order to have a broad overview of the nature of works written in relation to the current research. Campbell and Cocco (2004) using micro data revealed that fluctuations in house price affect household consumption through increased rent and a rise in loan installments. The fluctuations tend to impact more the older homeowners than the younger renters. A house which is wealth collected by older generation becomes less transferable and mobile as such changes in house price will affect consumption.

Johnson, Parker and Souleles (2006) investigated the change in consumer expenditure as a result of 2001 federal income tax rebates. They also tested the validity of the permanent income hypothesis. The consumers spent some 20 to 40 percent of their rebates on nondurable goods. The impact on consumption demand was substantial especially for those with low income and wealth. Aguiar and Hurst (2005) used a large cross-section data of United States households on food diaries disclosed that, "despite the decline in food expenditures, neither the quantity nor the quality of food intake deteriorates with retirement status". Hence a decline in consumption expenditures following retirement of the American people this phenomenon is offset by an equivalent rise in time spent on home production.

Chetty and Szeidl (2007) studied risk preferences in the utility theory dealing with consumption commitments since they believe that the majority of households spent a large portion of their income on consumption. Using portfolio analysis which is useful for determining between high and moderate risk aversion they come out with the optimal design for social insurance and tax policies.

\section{Methodology}

The methodology discussed in this section refers to the prosedure of sampling technique adopted in the current study and the construction of econometric model based on survey for the three states of east coast Malaysia: Pahang, Kelantan and Terengganu. A detailed explanation of research methodology employed in this study is discussed in the following section.

\section{Household Sample}

Simple random sampling technique was used as the basis in the selection of the respondents. Three states in the east coast of Peninsular Malaysia were selected namely Pahang, Kelantan and Terengganu. The selection of districts and sub-districts (mukims) was purposively chosen based on the suggestion from district officers due to their knowledge and wide experience about the survey areas. In Pahang, two selected districts were Kuantan (urban) and Pekan (rural), while for Kelantan, the selected districts were Kota Bharu (urban) and Kuala Krai (rural). Lastly for Terengganu, Kuala Terengganu and Setiu were chosen to represent the urban and rural area respectively. Based on mukims selected in each state, respondents were drawn by simple random sampling technique. 
Table 1 shows the ditribution of sampled respondents (households) by state and munacipality district. Altogather a total of 645 respondents were interviewed based on disproportionate percentage of the three states' sub-district populations. The breakdown shows that 218 households were interviewed in Pahang, 213 households in Kelantan and 214 households in Terengganu. As noted, the samples from each state were divided into rural and urban for which about the same number of samples were drawn from the rural area (314 households) and urban area (311 households). These sampled rural and urban households were stipulated to represent a sufficient number of representation from each stratum for the analysis.

Table 1

Distribution of Sampled Respondents by State and Selected District

\begin{tabular}{|c|c|c|c|c|c|}
\hline \multirow{2}{*}{ State } & \multicolumn{4}{|c|}{ Selected district } & \multirow{2}{*}{-Total sample } \\
\hline & Urban & Number of sample & Rural & Number of sample & \\
\hline Pahang & Kuantan & 118 & Pekan & 100 & 218 \\
\hline Kelantan & Kota Bharu & 110 & Kuala Krai & 104 & 214 \\
\hline Terengganu & Kuala Terengganu & 103 & Setiu & 110 & 213 \\
\hline Total & & 311 & & 314 & 625 \\
\hline
\end{tabular}

\section{Two-Stage Least Square Model}

The system of structural equations for simultaneous solutions of the reduced forms are shown below for identification of order condition (the rank condition is not shown for limitation of space). Most of the strtructural equations used in this study are over-identified as such that they have several solutions rather than a single solution as none of the equations is exactly identified. The only problem arising from identification of the simultaneous equation technique is the possiblity of no solution which occurs when the equation is found to be under-identified. This study employed the two stage least square (2SLS) statistical estimation procedure using SHAZAM software. Specifically other software, that is, the Satistical Package for Social Scireces (SPSS) was also used to verify the results and they were found to yield identical results for all states analyzed in this study.

The structural equations presented here are in general forms to differentiate between endogenous variables denoted by $Y_{i k}$ for $i=1,2, \ldots, p$ endogeous variables in the equation and $k=1,2, . ., m$ number of endogenous variables used in the model. The exogenous variables denoted by $X_{l j}$ for $l=1,2, \ldots, q$ number of endogenous variables in the equation and $j=k+1, k+2, \ldots, k+n$ number of exogenous variables in the model. The definitions of the variables used in the analyses are also provided to assist readers to refer to the actual variables names as presented in the tables.

The estimated income and expenditure structural equations (without the identity equation) are:

$$
\begin{aligned}
& \begin{array}{lllll}
Y_{1 t}-\beta_{10}-\beta_{12} Y_{2 t} & -\gamma_{14} X_{4 t} & -\gamma_{16} X_{6 t} & =\varepsilon_{1 t}
\end{array} \\
& Y_{2 t}-\beta_{20}-\beta_{21} Y_{1 t}-\gamma_{21} X_{1 t}-\gamma_{22} X_{2 t} \quad=\varepsilon_{2 t} \\
& Y_{3 t}-\beta_{30}-\beta_{31} Y_{1 t}-\beta_{32} Y_{2 t} \quad-\gamma_{34} X_{4 t} \quad-\gamma_{38} X_{8 t}=\varepsilon_{3 t} \\
& Y_{4 t}-\beta_{40}-\beta_{41} Y_{1 t}-\quad-\gamma_{41} X_{1 t}-\gamma_{42} X_{2 t} \quad=\varepsilon_{4 t} \\
& \begin{array}{lllll}
Y_{5 t}-\beta_{50} & -\beta_{52} Y_{2 t} & -\gamma_{54} X_{4 t} & -\gamma_{56} X_{6 t} & =\varepsilon_{5 t}
\end{array} \\
& Y_{6 t}-\beta_{60}-\beta_{61} Y_{1 t}-\quad-\gamma_{61} X_{1 t}-\gamma_{62} X_{2 t}-\gamma_{63} X_{3 t}-\gamma_{64} X_{4 t} \quad=\varepsilon_{6 t} \\
& Y_{7 t}-\beta_{70}-\beta_{71} Y_{1 t}-\beta_{72} Y_{2 t}-\beta_{73} Y_{3 t} \quad-\gamma_{74} X_{4 t}-\gamma_{75} X_{5 t}-\gamma_{76} X_{6 t} \quad=\varepsilon_{7 t}
\end{aligned}
$$

where: $Y_{1 t}$ is the monthly expenditure components (in $\mathrm{RM} / \mathrm{month}$ );

$Y_{2 t}$ represents household monthly income (in RM/month); 
$Y_{3 t}$ is expenditure for loan (RM/month);

$Y_{4 t}$ is expenditure for cloth (RM/month);

$Y_{5 t}$ is expenditure for food (RM/month);

$Y_{6 t}$ is total borrowing loan (RM/month);

$Y_{7 t}$ is the savings (RM/month);

$X_{I t}$ is housing loan (RM/month);

$X_{2 t}$ is automobile loan (RM/month);

$X_{3 t}$ is education loan (RM/month);

$X_{4 t}$ is family size (RM/month);

$X_{5 t}$ is refered to location with dummy value of 1 for the urban areas;

$X_{6 t}$ is represented as age level, HF as hospital's facilities;

$X_{7 t}$ is the sex; 1 = male, 0 = otherwise, (not utilized in actual estimation);

$X_{8 t}$ is the maritial status; 1 = single, $2=$ married, 3 = widow;

$\beta_{i k}$ are coefficients of regression for endogenous variables;

$\beta_{l j}$ are coefficients of regression for exogenous variables;

$\beta_{10}, \beta_{20}, \beta_{30}, \beta_{40}, \beta_{50}, \beta_{60}$ and $\beta_{70}$ are constant intercepts;

$\varepsilon_{1 t}, \varepsilon_{2 t}, \varepsilon_{3 t}, \varepsilon_{4 t}, \varepsilon_{5 t}, \varepsilon_{6 t}$ and $\varepsilon_{7 t}$ are the random error terms.

The identification tests for order condition are given as:

if $K-k>g-1$, the equation is "over-identified";

if $K-k<g-1$, the equation is "under-identified";

if $K-k=g-1$, the equation is "exactly-identified".

The notations are defined as:

$g$ = the number of endogenous variables in a equation system without intercept;

$K=$ the number of exogenous variables in the model including intercept;

$k=$ the number of exogenous variables in a given equation including intercept.

According to the previous studies, most of the researchers like Paulin (1995), Yen and Jensen (1996), Paulin (2000), Canagarajah and Newman (2001) and Yin and Guanghua (2006) used the age, sex, marital status and education level as the variables to represent individual characteristics. While, for the characteristic of household's variable, majority of the researchers used the household's size and the age level.

The null hypothesis of this study assumes that there is no significant association between expenditure and income, while the alternative hypotesis states that there is a direct association between income and expenditure. Theoretically, for a normal goods when income increases there is a strong tendency for the expenditure to increase accordingly. Similarly age, maritial status, sex, education level and the household size might have their influences on income and expenditure.

Nevertheless, the relation between age and expenditure are expected to be explained by a quadratic function whereby at the earlier stage in life expenditure will gradually rise to a maximum level consistent with the productive age of the wage earner. After this maximum expenditure, there is a tendency for expenditure to decline showing a negative correlation with the expenditure. It is hypothesized that as people get older they spend less on consumer goods and on foods outside the house and probably prefer to have food prepared at home. This 
hypothesis is parallel to the emprical research's finding of Wagner (1982) and Yin et al. (2005). While for the dummy variable on location, it is generally expected that the urban respondents expenditure is usually higher than the rural respondents because of the high cost of living in uraban compared to the rural area.

\section{Results and Discussion}

In general, $R^{2}$ varies widely with the lowest being 0.3 and the highest 0.9 . The lowest range is still acceptable because the study uses the cross-sectional data. Based on the result of 2SLS analysis as shown in Table 2, eight simultaneous equations were estimated for the state of Pahang.

Most of $t$-values for EXTO (total expenditure) equation in Pahang are significant at 0.01 and 0.05 probability levels in equation (1) in Table 2. Using EXTO as an endogenous variable there is positive relationship between INC (income) and EXTO. The computed income-expenditure elasticity discloses that one percent increase in income necessitates an increase of 0.21 percent in the total expenditure. This scenario is consistent with the Engel's theory, whereby an increase in income would generate a less than unity on food and as income further increases lesser proportion of income will be spent on food items. For rural community of the East Coast a large proportion of their income and expenditure is mostly allocated for food in equation (2) in Table 2. This positive relationship between income and total expenditure is expected and is constant with the microeconomic theory. A raise in income influences the spending behavior of the households. On the other hand, an increase in EXTO will have an impact on the household income, the magnitude of which is 0.71 and is highly significant at 0.01 probability level. This implies if total expenditure were to increase by 1 percent the household will have to increase higher, that is by 0.71 percent equation (2) in Table 2. In order to spend more the household will have to work extra time to obtain higher income.

While, for the variables such as HLO (housing loan) and ALO (automobile loan), they highly correlated with EXTO (total expenditure) at a significant level of 0.01. The reason for strong association between housing loan and automobile loan is obvious as these are the major investment expenditures of high priority for the majority of people. Most of them would like to spend more money to fulfill their family and individual needs by making loan for life long investments such as housing and automobile from financial institutions. Total borrowing loan (TBL) equation indicates that these variables: housing, automobile and education are statistically significant from zero. Moreover, if they are able to pay monthly installments on these assets, it would not be difficult to get loans from the banks.

With reference to equation (2) in Table 2, expenditure on food (EXF) shows high association with the total expenditure (EXTO) and family size (FSA). In all cases, they are positive implying that an increase in the total expenditure will increase spending on food, while the family size directly influences expenditure on food. Besides, on a lesser degree, age which is directly related to family size can be a possible contributor for an increase in expenditure on food.

The findings in Kelantan are more or less similar to that of Pahang. Most of $t$-values for equation (1) in Table 3 in Kelantan are significant at 0.05 and 0.01 probability levels. There is a positive relationship between INC (income) and endogenous variable, EXTO. Besides income, there are three other independent variables that have strong relationships with EXTO, namely expenditure for education (EXE), housing loan (HLO), and lastly the automobile loan (ALO). 
Referring to equation (2) in Table 3, the endogenous variable, INC is highly associated with five exogenous variables EXTO, FSA (family size), DEP (dependent), DSE (dummy for self-employment) and DUE (dummy for unemployment). These findings evidently affirm the fact that variations in the family size and dependents strongly contributed to the variation in income.

Table 2

Results of 2SLS Regression Analysis for Pahang

\begin{tabular}{|c|c|c|c|c|c|c|c|c|}
\hline \multirow[b]{2}{*}{ Regressor } & \multicolumn{8}{|c|}{ Endogenous variables } \\
\hline & $\begin{array}{l}\text { EXTO } \\
\text { (equation (1)) }\end{array}$ & EXF & EXC & EXE & SAV & TBL & $\begin{array}{l}\text { INC } \\
\text { (equation (2)) }\end{array}$ & EXL \\
\hline Constant & $\begin{array}{l}593.37 \\
(3.127)^{* * * *}\end{array}$ & $\begin{array}{l}50.457 \\
(0.8788)\end{array}$ & $\begin{array}{l}-185.16 \\
(-1.983)^{* *}\end{array}$ & $\begin{array}{c}-105.28 \\
(-1.774)^{* *}\end{array}$ & $\begin{array}{l}93.024 \\
(0.9972)\end{array}$ & $\begin{array}{r}9.3627 \\
(0.253)\end{array}$ & $\begin{array}{l}-204.62 \\
(-0.2916)\end{array}$ & $\begin{array}{l}-254.57 \\
(-1.715)^{* *}\end{array}$ \\
\hline EXTO & & $\begin{array}{c}0.1339 \\
(10.69)^{* * *}\end{array}$ & $\begin{array}{l}0.1184 \\
(2.987)^{* * *}\end{array}$ & & $\begin{array}{c}0.04215 \\
(0.5834)\end{array}$ & & $\begin{array}{l}1.2146 \\
(7.809)^{* * *}\end{array}$ & $\begin{array}{l}0.623 \\
(5.715)^{* * *}\end{array}$ \\
\hline INC & $\begin{array}{l}0.1207 \\
(1.808)^{* *}\end{array}$ & & & $\begin{array}{c}0.00209 \\
(0.1405)\end{array}$ & $\begin{array}{c}0.05506 \\
(1.1013)\end{array}$ & $\begin{array}{c}0.00612 \\
(0.4128)\end{array}$ & & $\begin{array}{r}-0.07507 \\
(-0.8983)\end{array}$ \\
\hline HLO & $\begin{array}{l}1.2539 \\
(4.475)^{* * *}\end{array}$ & & & & & $\begin{array}{c}1.1058 \\
(21.05)^{* * *}\end{array}$ & & \\
\hline ALO & $\begin{array}{l}0.948 \\
(3.244)^{* * * *}\end{array}$ & & $\begin{array}{c}-0.1184 \\
(-1.057)\end{array}$ & & & $\begin{array}{c}1.0478 \\
(20.63)^{* * * *}\end{array}$ & & \\
\hline FSA & & $\begin{array}{l}20.779 \\
(3.422)^{* * *}\end{array}$ & & & $\begin{array}{r}-33.942 \\
(-1.05)\end{array}$ & $\begin{array}{c}2.6439 \\
(0.3979)\end{array}$ & $\begin{array}{l}546.72 \\
(4.738)^{* * *}\end{array}$ & $\begin{array}{l}25.319 \\
(0.4503)\end{array}$ \\
\hline AGE & & $\begin{array}{c}1.6877 \\
(1.759)^{*}\end{array}$ & $\begin{array}{c}1.9913 \\
(1.304)\end{array}$ & & $\begin{array}{c}-0.5563 \\
(-0.3261)\end{array}$ & & $\begin{array}{l}19.937 \\
(1.835)\end{array}$ & \\
\hline EXT & & & & $\begin{array}{l}0.6924 \\
(2.056)^{* *}\end{array}$ & & & & \\
\hline EXE & $\begin{array}{l}3.0281 \\
(3.197)^{* * * *}\end{array}$ & & & & & & & \\
\hline EDLO & & & & $\begin{array}{l}-0.00995 \\
(-1.044)\end{array}$ & & $\begin{array}{c}0.9955 \\
(10.77)^{* * * *}\end{array}$ & & \\
\hline TBL & & & & $\begin{array}{c}0.02925 \\
(0.5981)\end{array}$ & & & & \\
\hline DEP & & & $\begin{array}{l}28.408 \\
(2.559)^{* *}\end{array}$ & $\begin{array}{l}22.723 \\
(3.3260)^{* * * *}\end{array}$ & $\begin{array}{c}5.1121 \\
(0.1466)\end{array}$ & & $\begin{array}{l}-593.59 \\
(-4.963)^{* * * *}\end{array}$ & $\begin{array}{l}-81.063 \\
(-1.381)\end{array}$ \\
\hline DPE & & & & $\begin{array}{l}-20.238 \\
(-0.5295)\end{array}$ & & & $\begin{array}{l}-261.97 \\
(-0.6156)\end{array}$ & $\begin{array}{l}-100.83 \\
(-0.9873)\end{array}$ \\
\hline DSE & & & & $\begin{array}{l}32.554 \\
(0.8906)\end{array}$ & & & $\begin{array}{c}-586.13 \\
(-1.388)\end{array}$ & $\begin{array}{l}-35.931 \\
(-0.3439)\end{array}$ \\
\hline DUE & & & & $\begin{array}{l}45.403 \\
(1.149)\end{array}$ & & & $\begin{array}{r}-475.37 \\
(-1.041)\end{array}$ & $\begin{array}{l}31.354 \\
(0.2813)\end{array}$ \\
\hline SEX & & & & $\begin{array}{l}-14.968 \\
(-0.5297)\end{array}$ & & & & \\
\hline MST & & & & & & & & $\begin{array}{l}-31.917 \\
(-0.3394)\end{array}$ \\
\hline LOC & & & & & $\begin{array}{l}72.742 \\
(1.645)\end{array}$ & & & \\
\hline $\mathrm{R}^{2}$ & 0.592 & 0.583 & 0.362 & 0.309 & 0.385 & 0.929 & 0.376 & 0.586 \\
\hline $\mathrm{DW}$ & 1.938 & 1.631 & 1.745 & 1.811 & 1.892 & 1.793 & 1.904 & 1.620 \\
\hline
\end{tabular}


Table 3

Results of 2SLS Regression Analysis for Kelantan

\begin{tabular}{|c|c|c|c|c|c|c|}
\hline \multirow{2}{*}{ Regressor } & \multicolumn{6}{|c|}{ Endogenous variables } \\
\hline & EXTO (equation (1)) & EXF & EXE & TBL & INC (equation (2)) & EXL \\
\hline Constant & $\begin{array}{l}399.93 \\
(4.587)^{* * *}\end{array}$ & $\begin{array}{l}53.191 \\
(0.795)\end{array}$ & $\begin{array}{l}17.241 \\
(0.5165)\end{array}$ & $\begin{array}{l}194.39 \\
(2.355)^{* *}\end{array}$ & $\begin{array}{r}-171.26 \\
(-0.2954)\end{array}$ & $\begin{array}{l}-416.18 \\
(-3.847)^{* * *}\end{array}$ \\
\hline EXTO & & $\begin{array}{l}0.1454 \\
(8.039)^{* * *}\end{array}$ & & & $\begin{array}{l}1.3411 \\
(8.387)^{* * *}\end{array}$ & $\begin{array}{l}0.7407 \\
(7.609)^{* * *}\end{array}$ \\
\hline EXE & $\begin{array}{c}3.0656 \\
(5.81)^{* * *}\end{array}$ & & & & & \\
\hline INC & $\begin{array}{c}0.0881 \\
(2.114)^{* *}\end{array}$ & & $\begin{array}{c}0.00569 \\
(0.5587)\end{array}$ & $\begin{array}{c}-0.01586 \\
(-0.3653)\end{array}$ & & $\begin{array}{c}-0.0704 \\
(-1.064)\end{array}$ \\
\hline HLO & $\begin{array}{c}1.4789 \\
(6.447)^{* *}\end{array}$ & & & $\begin{array}{c}1.5557 \\
(7.209)^{* * *}\end{array}$ & & \\
\hline ALO & $\begin{array}{c}1.0093 \\
(6.377)^{* *}\end{array}$ & & & $\begin{array}{c}1.0551 \\
(7.362)^{* * *}\end{array}$ & & \\
\hline FSA & & $\begin{array}{c}4.5656 \\
(0.8886)\end{array}$ & & $\begin{array}{c}-7.2618 \\
(-0.4676)\end{array}$ & $\begin{array}{l}342.37 \\
(5.899)^{* * *}\end{array}$ & $\begin{array}{l}12.183 \\
(0.4433)\end{array}$ \\
\hline AGE & & $\begin{array}{c}2.3312 \\
(2.072)^{* *}\end{array}$ & & & $\begin{array}{l}10.781 \\
(1.119)\end{array}$ & \\
\hline EXT & & & $\begin{array}{c}0.0698 \\
(0.542)\end{array}$ & & & \\
\hline EDLO & & & $\begin{array}{c}0.0511 \\
(2.135)^{* *}\end{array}$ & $\begin{array}{r}0.9731 \\
(12.5)^{* * *}\end{array}$ & & \\
\hline TBL & & & $\begin{array}{c}-0.00188 \\
(-0.1088)\end{array}$ & & & \\
\hline DEP & & & $\begin{array}{l}26.422 \\
(6.545)^{* * *}\end{array}$ & & $\begin{array}{l}-370.82 \\
(-5.268)^{* * *}\end{array}$ & $\begin{array}{l}-60.343 \\
(-2.019)^{* *}\end{array}$ \\
\hline DPE & & & $\begin{array}{c}-5.6517 \\
(-0.2201)\end{array}$ & & $\begin{array}{r}-361.00 \\
(-1.049)\end{array}$ & $\begin{array}{l}-57.645 \\
(-0.6626)\end{array}$ \\
\hline DSE & & & $\begin{array}{l}-19.89 \\
(-0.8924)\end{array}$ & & $\begin{array}{l}-506.44 \\
(-1.726)^{* *}\end{array}$ & $\begin{array}{l}90.486 \\
(1.162)\end{array}$ \\
\hline DUE & & & $\begin{array}{l}-11.224 \\
(-0.4147)\end{array}$ & & $\begin{array}{l}-904.18 \\
(-2.741)^{* * *}\end{array}$ & $\begin{array}{c}-0.5819 \\
(-0.00599)\end{array}$ \\
\hline SEX & & & $\begin{array}{l}-24.285 \\
(-1.407)\end{array}$ & & & \\
\hline MST & & & & & & $\begin{array}{c}6.8921 \\
(0.0954)\end{array}$ \\
\hline$\overline{\mathrm{R}^{2}}$ & 0.6493 & 0.4439 & 0.3314 & 0.6831 & 0.3949 & 0.4953 \\
\hline$\overline{\mathrm{DW}}$ & 1.9334 & 1.7258 & 1.8048 & 1.9356 & 1.6200 & 1.7707 \\
\hline
\end{tabular}

Notes: ${ }^{* *}$ significant at 0.05 probability level; ${ }^{* * *}$ significant at 0.01 probability level.

As shown in Table 4, Terengganu has five equations with significant variables at $99 \%$, 95\% and $90 \%$. Most of $t$-values for equation (1) in Table 4 in Terengganu are significant at 0.01 . There is a positive relationship between INC and endogenous variable, EXTO. In contrast to the case of Pahang and Kelantan, the relationship between income and total expenditure in Terengganu is not significant. The highest $R^{2}$ value in total borrowing loan (TBL) means that Terengganu households tend to spend money from borrowed income since they have 
insufficient earnings. In Terengganu, income does not constitute significantly to the variation in the households' expenditure. Nevertheless, there are three independent variables that have strong relationships with EXTO at 0.05 and 0.01 significant levels. These variables are identified as EXE (Expenditures for education), INC (Income), HLO (Housing loan), and lastly ALO (Automobile loan).

Table 4

Results of 2SLS Regression Analysis for Terengganu

\begin{tabular}{|c|c|c|c|c|c|}
\hline \multirow{2}{*}{ Regressor } & \multicolumn{5}{|c|}{ Endogenous variables } \\
\hline & EXTO (equation (1)) & EXF & INC (equation (2)) & TBL & EXL \\
\hline Constant & $\begin{array}{l}458.52 \\
(3.534)^{* * *}\end{array}$ & $\begin{array}{c}13.774 \\
(0.162)\end{array}$ & $\begin{array}{l}3565.0 \\
\quad(3.723)^{* * *}\end{array}$ & $\begin{array}{c}-164.09 \\
(-2.223)^{* *}\end{array}$ & $\begin{array}{c}-546.29 \\
(-2.746)^{* * *}\end{array}$ \\
\hline ЕXTO & & $\begin{array}{c}0.0905 \\
(5.37)^{* * *}\end{array}$ & $\begin{array}{c}0.8776 \\
(4.328)^{* * *}\end{array}$ & & $\begin{array}{r}0.07594 \\
(10.39)^{* * *}\end{array}$ \\
\hline INC & $\begin{array}{l}0.07515 \\
(1.436)\end{array}$ & & & $\begin{array}{l}0.069 \\
(2.677)^{* * *}\end{array}$ & $\begin{array}{l}0.07096 \\
(-1.185)\end{array}$ \\
\hline HLO & $\begin{array}{l}1.3856 \\
(9.011)^{* * *}\end{array}$ & & & $\begin{array}{c}1.001 \\
(15.34)^{* * *}\end{array}$ & \\
\hline ALO & $\begin{array}{c}1.4144 \\
(6.948)^{* * *}\end{array}$ & & & $\begin{array}{c}0.7556 \\
(8.223)^{* * *}\end{array}$ & \\
\hline FSA & & $\begin{array}{l}20.288 \\
(3.565)^{* * *}\end{array}$ & $\begin{array}{l}161.33 \\
(2.099)^{* *}\end{array}$ & $\begin{array}{l}12.519 \\
(1.765)^{* *}\end{array}$ & $\begin{array}{l}23.34 \\
(1.203)\end{array}$ \\
\hline AGE & & $\begin{array}{c}2.9636 \\
(2.309)^{* *}\end{array}$ & $\begin{array}{l}-24.661 \\
(-2.069)^{* *}\end{array}$ & & \\
\hline $\mathrm{EXT}$ & & & & & \\
\hline EXE & $\begin{array}{l}3.046 \\
(6.565)^{* * *}\end{array}$ & & & & \\
\hline EDLO & & & & $\begin{array}{c}0.8633 \\
(10.74)^{* * *}\end{array}$ & \\
\hline DEP & & & $\begin{array}{l}-359.8 \\
(-4.582)^{* *}\end{array}$ & & $\begin{array}{l}-86.608 \\
(-3.30)^{* * *}\end{array}$ \\
\hline DPE & & & $\begin{array}{l}-385.44 \\
(-0.8428)\end{array}$ & & $\begin{array}{c}141.41 \\
(1.295)\end{array}$ \\
\hline DSE & & & $\begin{array}{r}-766.03 \\
(-1.645)\end{array}$ & & $\begin{array}{l}351.97 \\
\quad(3.001)^{* * *}\end{array}$ \\
\hline DUE & & & $\begin{array}{r}-156.67 \\
(-0.309)\end{array}$ & & $\begin{array}{l}351.91 \\
\quad(2.928)^{* * *}\end{array}$ \\
\hline SEX & & & & & \\
\hline MST & & & & & $\begin{array}{r}-113.69 \\
(-0.9866) \\
\end{array}$ \\
\hline $\mathrm{R}^{2}$ & 0.7127 & 0.3083 & 0.3019 & 0.8226 & 0.482 \\
\hline DW & 1.5575 & 1.5612 & 1.7637 & 2.0195 & 1.7979 \\
\hline
\end{tabular}

Notes: ${ }^{* *}$ significant at 0.05 probability level; ${ }^{* * *}$ significant at 0.01 probability level.

For equation (2) in Table 4, INC is highly correlated to exogenous variables EXTO, FSA, AGE and DEP at 0.01 and 0.05 significant levels. Compared to Pahang and Kelantan, Terengganu exhibits strong relationship 
between INC and AGE indicating that as age increases respondents earn smaller income as such they contribute less to the job market. The majority of respondent experience substantial reduction in income as they attained retirement age which in turn affects their expenditure patterns.

Table 5 shows the relationship between mean income and mean total expenditure for the three states. The mean income is directly proportional to and has a positive relationship with the total expenditure. In other words, an increase in income will increase the total expenditure. Therefore, it is clear that total expenditure is influenced by income of the household. On the average, the amount of total expenditure for Pahang is the highest and for Kelantan it is the lowest. The proportion of expenditure in Kelantan is about 68.4 to 69.1 percent of that of the state of Pahang and apparently as Kelantan total income increases relative to Pahang the proportion of spending for the state gradually rises. In Terengganu the proportion of total expenditure in relation to Pahang is higher, that is, 91-92 percent for income group of RM 200-RM 600 per month. This figure seems to decline to 88-87 percent as total income rises to RM 2,000-RM 2,400 per month.

Table 5

Average Income and Expenditure for the East Coast Households

\begin{tabular}{|c|c|c|c|c|c|}
\hline \multirow{2}{*}{ Monthly average income (RMy) ${ }^{\mathrm{a}}$} & \multicolumn{3}{|c|}{ Average total expenditure } & \multirow{2}{*}{$-(2) /(1)$} & \multirow{2}{*}{$(3) /(1)$} \\
\hline & Pahang (1) & Kelantan (2) & Terengganu (3) & & \\
\hline 200 & $1,453.67$ & 994.39 & $1,336.26$ & 0.684 & 0.919 \\
\hline 400 & $1,477.81$ & $1,012.01$ & $1,351.29$ & 0.685 & 0.914 \\
\hline 600 & $1,501.95$ & $1,029.63$ & $1,366.32$ & 0.686 & 0.910 \\
\hline 800 & $1,526.09$ & $1,047.25$ & $1,381.35$ & 0.686 & 0.905 \\
\hline 1,000 & $1,550.23$ & $1,064.87$ & $1,396.38$ & 0.687 & 0.901 \\
\hline 1,200 & $1,574.37$ & $1,082.49$ & $1,411.41$ & 0.688 & 0.896 \\
\hline 1,400 & $1,598.51$ & $1,100.11$ & $1,426.44$ & 0.688 & 0.892 \\
\hline 1,600 & $1,622.65$ & $1,117.73$ & $1,441.47$ & 0.689 & 0.888 \\
\hline 1,800 & $1,646.79$ & $1,135.35$ & $1,456.5$ & 0.689 & 0.884 \\
\hline 2,000 & $1,670.93$ & 1,152.97 & $1,471.53$ & 0.690 & 0.881 \\
\hline 2,200 & $1,695.07$ & $1,170.59$ & $1,486.56$ & 0.691 & 0.877 \\
\hline 2,400 & $1,719.21$ & $1,188.21$ & $1,501.59$ & 0.691 & 0.873 \\
\hline
\end{tabular}

Note. ${ }^{\mathrm{a}}$ US\$ 1 = RMy 3.1.

\section{Conclusion}

Based on this study, it can be summarized that the current economic situation has affected the consumers' incomes and expenditures. The finding revealed that total expenditure varies slightly between the three states but most of their income were utilized for housing loan, automobile loan and expenditures on food and education. Further finding discloses the fact that saving for all states was apparently minimal and in most cases this variable is not significantly different from zero in all estimated 2SLS models. Respondents in the state of Kelantan could be more suffering from the current global economic crisis because they exhibit the lowest mean expenditures relative to other states of Pahang and Terengganu. Basically, the surveys conducted among households of the East Coast of Peninsular Malaysia seem to support the following conclusions. 
Increasing cost of living as reflected in higher attainment of gross domestic product (GDP) overtime at the macro level as well as due to increased petroleum and commodity prices have somehow forced the households to spend more money in order to be attained to their spending before the crisis.

Lower income households especially for the rural people could still survive the economic condition since most of them might turn to borrowing as evident from the study whereby borrowings from financial institutions are prevalent among the surveyed households.

In terms of government responsibility and role, there should be an advisory committee to limit borrowing and promote campaign in order to educate households to spend wisely.

Households should spend wisely according to their urgent needs. A budget is the best way to help check and direct their spending. By setting amounts for the budget categories, it can assure that they fit to their personal preferences. Individual consciousness is the key point to be emphasized to make sure that households are careful in spending their income. They should be encouraged to save for their future needs. In short, learning to manage the money wisely takes time and effort. Surely, it depends on individuals in the society and their realization of the importance of saving.

\section{References}

Aguiar, M., \& Hurst, E. (2005). Consumption versus expenditure. Journal of Political Economy, 113(5), 919-933.

Atsushi, M. (2006). Changes in japanese household consumption and saving behavior before, during and after the bubble era: Empirical analysis using NSFIE micro-data sets. Japan and the World Economy, 2-21.

Beine, M., Bismans, F., Docquier, F., \& Laurent, S. (2001). Life-cycle behavior of US household: A nonlinear GMM estimation on pseudo panel data. Journal of Policy Modeling, 713-729.

Campbell, J. Y., \& Cocco, J. F. (2004). How do house prices affect consumption? Evidence from micro data. Harvard Institute of Economic Research. Discussion Paper No. 2045. Harvard University Cambridge, Massachusetts.

Canagarajah, S., \& Newman, C. (2001). Non-farm income, gender, and inequality: Evidence from rural Ghana and Uganda. Food Policy, 26(2001), 405-420.

Chetty, R., \& Szeidl, A. (2007). Consumption commitments and risk preferences. The Quarterly Journal of Economics, 122(2), 831-877.

Cutler, J. (2005). The relationship between consumption, income and wealth in Hong Kong. Pacific Economic Review, 10(2), 217-241.

Dejuan, J. P., \& Seater, J. J. (1999). The permanent income hypothesis: Evidence from the consumer expenditure survey. Journal of Monetary Economics, 43, 351-376.

Farkhanda, S., \& Eatzaz, A. (2007). Understanding household consumption patterns in Pakistan. Journal of Retailing and Consumer Services, 150-164.

Johnson, D. S., Parker, J. A., \& Souleles, N. S. (2006). Household expenditure and the income tax rebates of 2001. The American Economic Review, 96(5), 1589-1610.

Othman, A. S. (1996). Poverty eradication from Islamic perspectives. Retrieved December 2009 from http://vlib.unitarkl1.edu.my/staff-publications/datuk

Yin, Z., \& Guanghua, W. (2006). The impact of growth and inequality on rural poverty in China. Journal of Comparative Economics, 34(2006), 694-712.

Zurawicki, L., \& Braidot, N. (2005). Consumers during crisis: Responses from the middle class in Argentina. Journal of Business Research, 1100-1109. 